\title{
STUDY OF DEMOGRAPHIC PROFILE OF PATIENTS WITH LUNG MALIGNANCIES
}

\author{
Pankaj Namdeorao Kadam¹, Santosh Narayan Pawar'2, Shubha Arvind Deshpande ${ }^{3}$, Nafela Siddiki ${ }^{4}$ \\ ${ }_{1}^{1}$ Assistant Professor, Department of Pathology, Dr. Shankarrao Chavan Government Medical College, Nanded. \\ ${ }^{2}$ Assistant Professor, Department of Pathology, Dr. Shankarrao Chavan Government Medical College, Nanded. \\ 3 Professor, Department of Pathology, Dr. Shankarrao Chavan Government Medical College, Nanded. \\ ${ }_{4}^{4}$ Resident, Department of Pathology, Dr. Shankarrao Chavan Government Medical College, Nanded.
}

\section{BACKGROUND}

ABSTRACT

Lung malignancy was typically described as a disease of industrial revolution and urbanisation, but with rampant tobacco abuse it reached epidemic proportions. The disease was typically confined to middle aged to elderly smokers, but the changing demographics and habits have shown an increasing trend of lung malignancy in females and non-smokers. Even after long and laborious years of research, lung malignancies even today beseech curative treatment.

\section{MATERIALS AND METHODS}

The present study is a prospective, hospital based, descriptive study. We use cell block method for diagnosis of lung cancers and by analysing history of patients we prepared demographic data.

\section{RESULTS}

We conducted a study of diagnosis of lung malignancy by cell block method. We studied a total of 75 samples from clinically suspected patients with lung malignancies. We found 48 patients with lung malignancy. We found in our study incidence of lung malignancy is more in Males (66.66\%) than in Females (33.33\%) due to smoking pattern and occupational exposure to hazardous carcinogens. Lung malignancy most commonly affects older population, people with age more than 50 are at more risk. Patients with age group 51 - 60 years (56.25\%) are most affected. People living in rural (70.83\%) areas are at more risk of developing lung cancer as compared to people living in urban (29.16\%) areas due to smoking habits and more exposure to environmental carcinogen. Labourers $(41.66 \%)$ are most affected population than other occupation due to occupational exposure to industrial carcinogens. People having history of smoking (79.16\%) are more prone to develop lung malignancy than non-smokers (20.83\%). Bidi $(78.94 \%)$ is the most common indigenous smoking pattern used by patients, as it is easily available and cheap.

\section{CONCLUSION}

By studying demographic profile, we conclude that environmental pollutants and smoking carcinogens made people more prone to lung cancers than normal people.

\section{KEYWORDS}

Cell Block, Lung Malignancies.

HOW TO CITE THIS ARTICLE: Kadam PN, Pawar SN, Deshpande SA, et al. Study of demographic profile of patients with lung malignancies. J. Evolution Med. Dent. Sci. 2018;7(01):98-106, DOI: 10.14260/jemds/2018/22

\section{BACKGROUND}

Cancer is known as the "Emperor of Maladies" and pulmonary malignancy is the undisputed king. Lung malignancies are the most common cancer afflicting the human race and which far outruns any malignancy in sheer number and worse prognosis.

Lung malignancy was typically described as a disease of industrial revolution and urbanisation, but with rampant tobacco abuse it reached epidemic proportions.

The disease was typically confined to middle aged to elderly smokers, but the changing demographics and habits have shown an increasing trend of lung malignancy in females and non-smokers.

Even after long and laborious years of research, lung malignancies even today beseech curative treatment.

'Financial or Other Competing Interest': None.

Submission 11-11-2017, Peer Review 10-12-2017,

Acceptance 16-12-2017, Published 01-01-2018.

Corresponding Author:

Dr. Santosh Narayan Pawar,

G-02, Shiv Residency,

Patel Nagar, Sathe Chowk, Nanded.

E-mail: santoshpawargp@yahoo.co.in

DOI: $10.14260 /$ jemds $/ 2018 / 22$

\section{Aims and Objectives}

To study demographic profile of patients with lung malignancies.

\section{MATERIALS AND METHODS}

Place- Tertiary Care Hospital.

\section{Study Population}

Patients admitted under Department of Pulmonary Medicine and Department of Medicine with features suggestive of lung malignancies, e.g. haemoptysis, recurrent pleural effusion, cervical and mediastinal lymphadenopathy and patients presenting with undiagnosed lung masses on radiology.

\section{Study Design}

The present study is a prospective, hospital based, descriptive study.

\section{Study Period}

18 months from 01-01-2013 to 30-06-2014.

\section{Inclusion Criteria}

Patients admitted under Department of Pulmonary Medicine and Department of Medicine with features suggestive of lung 
malignancies e.g. Haemoptysis, Recurrent pleural effusion, Cervical and Mediastinal lymphadenopathy and Patients presenting with undiagnosed lung masses on radiology.

\section{Exclusion Criteria}

Diagnosed patients with lung malignancies are excluded from the study.

\section{Methodology/ The Study Variables-}

Socio-Demographic Characters-

1. Name.

2. Age.

3. Sex.

4. Caste/ Religion.

5. Residence.

\section{Clinical History}

1. Presenting Complaints.

2. Any Hospitalisation in past.

3. Past History.

4. Family History.

5. Chronic Illness.

6. Physical Examination: General and Systemic examination.

\section{Laboratory Parameters}

1. Baseline Haematological tests: $\mathrm{Hb}, \mathrm{CBC}$, Platelet Count.

2. Liver Function Test.

3. Kidney Function Test.

4. Pleural Fluid Biochemistry: Glucose, Protein, LDH.

\section{Radiological Investigations}

1. X-ray chest.

2. Ultrasonography of chest.

3. Computed tomography of chest.

\section{All Patients Suspicious for Lung Malignancy were Evaluated}

- After detailed clinical and personal history, general and clinical examination was noted.

- $\quad$ Radiological examinations like X-ray chest, CT-chest and USG chest were also taken into consideration.

- Patients were clinically suspected for lung malignancy, classified according to nature of sample received as-

1. Patients Presenting with Pleural Effusion-

After informed and written consent, under strict aseptic precautions pleural fluid tapping was performed in wards by clinicians and $10 \mathrm{~mL}$ of pleural fluid was sent to cytology lab in EDTA anticoagulated bulb within 2 hours of tapping. The samples were immediately processed by conventional cytological smear preparation and on cell block preparation if found positive or suspicious for malignancy, hence same sample was evaluated for comparative study.

\section{Other samples used are-}

\section{USG-guided FNAC of Lung Mass-}

Tissue sample obtained by FNAC were also processed, both on routine cytology slide and cell block method.

\section{Bronchoalveolar Lavage (BAL) Cytology-}

Tissue sample obtained by BAL were also processed, both on routine cytology slide and cell block method.
Technique of Conventional Smear Preparation-

$5 \mathrm{~mL}$ pleural fluid sample centrifuged at $2500 \mathrm{rpm}$ for 15 mins, then a thin smear was prepared from sediment. Cytological smear was stained by haematoxylin-eosin stain.
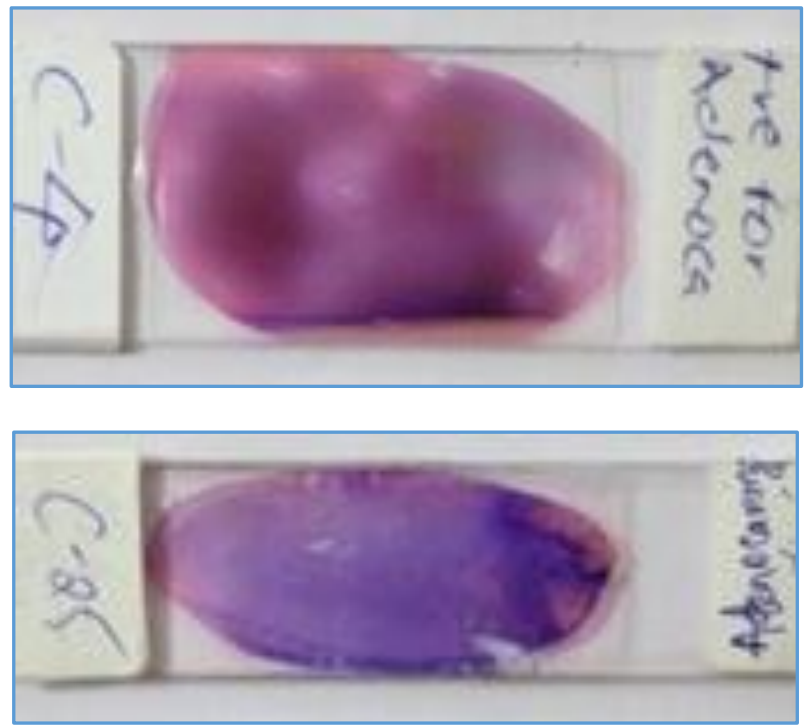

Image 1. H and E Stained Slide of Conventional Smear

\section{Haematoxylin-Eosin Staining Method for Conventional Method}

After making smear from sediment on slide, slide is fixed in methanol after that slide dip in Haematoxylin for 15 mins, then slide washed with tap water and dip in eosin for $1 \mathrm{~min}$. Slide mount with DPX and observed under microscope.

\section{Technique of Cell Block Preparation}

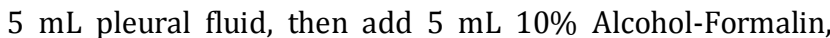
keep for 1 hour, then centrifuge for $2500 \mathrm{rpm}$ for 15 mins. Discard supernatant and again add $3 \mathrm{~mL} 10 \%$ alcoholFormalin for $24 \mathrm{hrs}$. to cell button. After overnight fixation scoop out cell button and process as routine histopathology specimens.

\section{RESULTS}

\section{Observations}

The interpretation of conventional smear and cell block.

The Samples were studied in detail, taking into account the available Clinical Data, various Investigation Reports and Microscopic Details. The Samples were categorised as-

1. Positive for Malignancy (PFM).

2. Suspicious for Malignancy (SFM)

3. Negative for Malignancy (NFM).

The Morphological Criteria that were taken into Account included the-

1. Cellularity.

2. Arrangement of the cells (acini, papillae and cell balls).

3. Cytoplasmic and the nuclear details of suspicious or malignant cells.

4. Presence of inflammatory cells like lymphocytes, polymorphs and mesothelial cells. 
All these criteria were put together and they were used for the categorisation of the sample. The cytomorphological characters were studied in detail to identify the malignancy.

A comparative evaluation of the $\mathrm{CS}$ versus the $\mathrm{CB}$ techniques was conducted.

\section{Interpretation of Conventional Smear}

1. Positive for Malignant Cells (PFM).

2. Suspicious for Malignancy (SMF).

3. Negative for Malignancy (NFM).

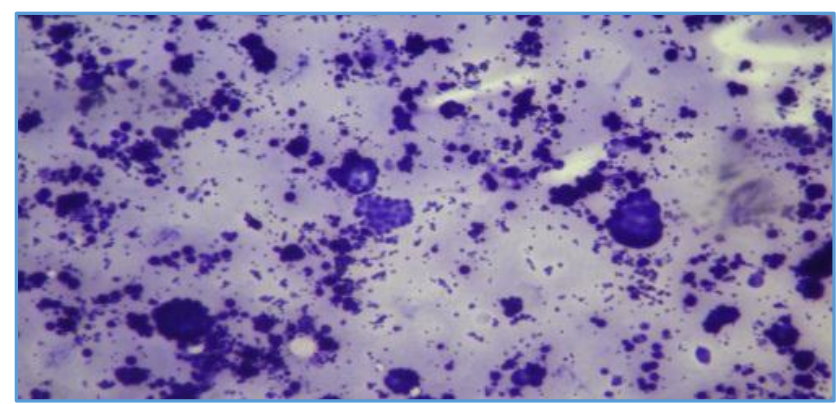

Image 2. Low Power (10x) H and E-Pleural Fluid Cytology

Smear study shows presence of Round-to-Oval atypical cells arranged in groups against inflammatory and mucinous background.

Diagnosis given- Suspicious for Malignant Cells (SFM).

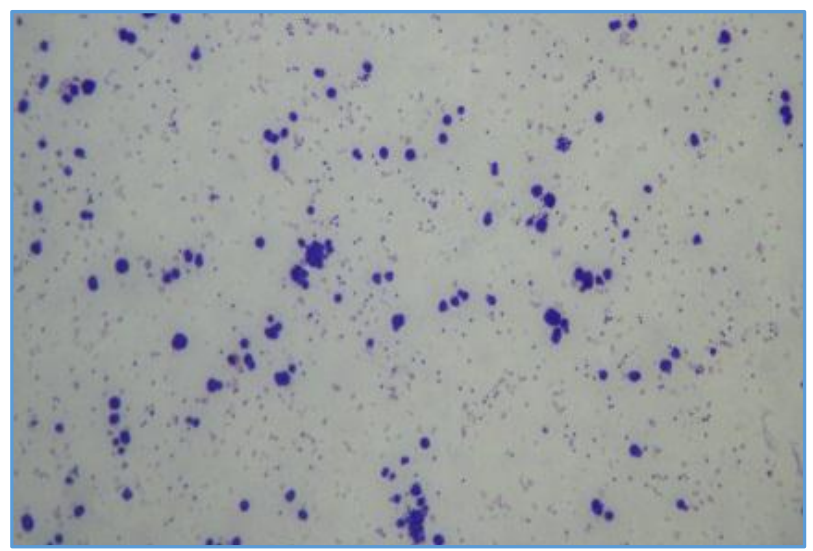

Image 3. Low Power H and E-Pleural Fluid

Cytology on Conventional Smear

Smear study shows scattered round-to-oval tumour cell over background of RBCs and inflammatory cells.

Diagnosis was given- Suspicious of Malignancy (SFM).

(Adv.: Cell Block Cytology).

Possible-Adv.: Cell Block Cytology).

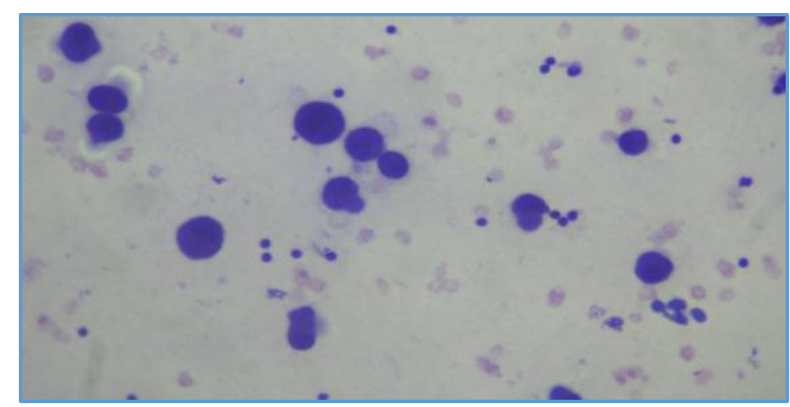

Image 4. High Power H and E Pleural Fluid Cytology
Smear study shows presence of round-to-oval tumour cells having hyperchromatic, pleomorphic nuclei and scant cytoplasm against haemorrhagic background.

Diagnosis given- Positive for Malignant cells (PFM).

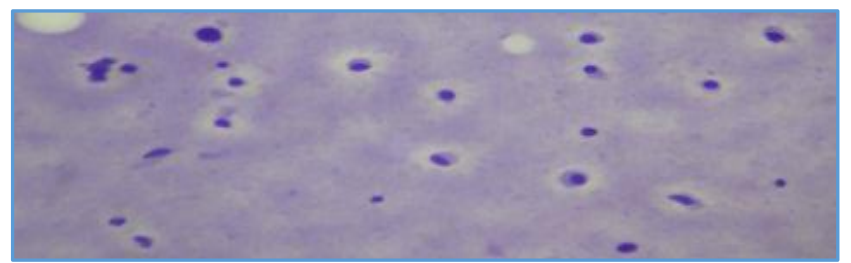

Image 5. Pleural Fluid Cytology- High Power H and E Smear Study shows Atypical Cells with Eccentric Nuclei with Moderate Amount of Cytoplasm

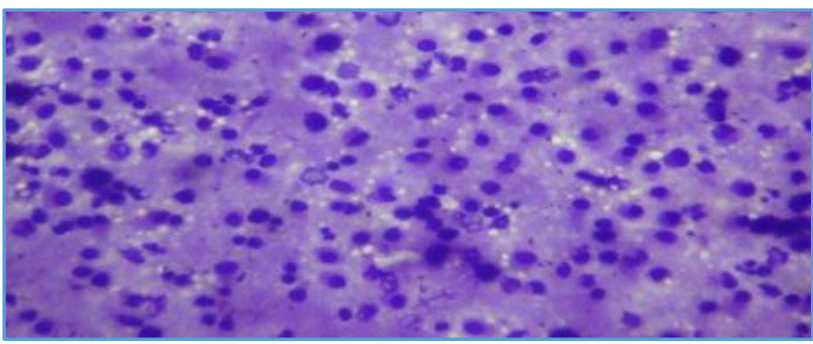

Image 6. Pleural Fluid Cytology

High power $\mathrm{H}$ and $\mathrm{E}$ stained-smear study shows many large cells having hyperchromatic pleomorphic nuclei and scanty cytoplasm on necrotic background material.

Diagnosis was given- Positive for Malignant cells (PFM)typing not possible.

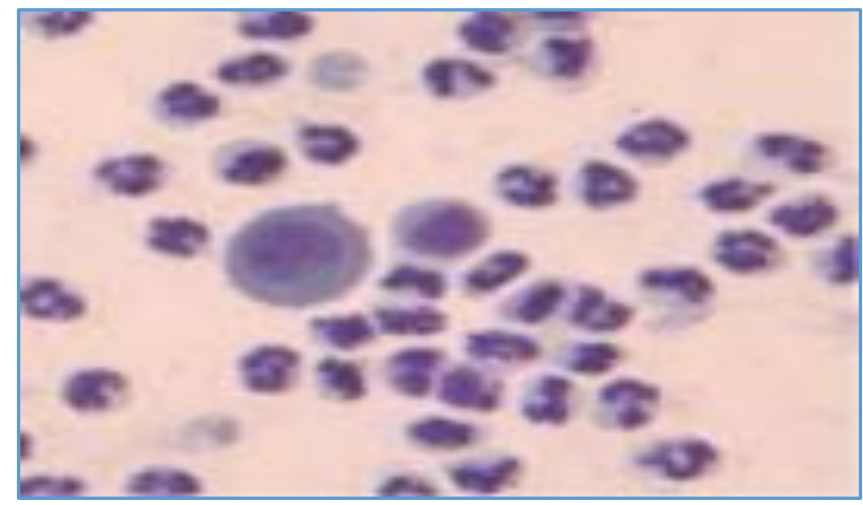

Image 7. H and E-High-Power Pleural Fluid Cytology Smear Study shows Presence of Plenty of Polymorphs, a Reactive Mesothelial Cell

Diagnosis given was Negative for Malignancy (NFM)/Inflammatory Smear.

\section{Interpretation of Cell Block Cytology}

Smear which are positive and suspicious for malignancy are processed on cell block. Due to better architectural pattern, cellularity, greater nuclear and cytoplasmic details typing of lung malignancies were possible. Smears were interpreted as- 


\section{Positive for Malignant Cells}

And given further histological typing. E.g. Adenocarcinoma of lung, squamous cell carcinoma lung, small cell carcinoma lung etc.

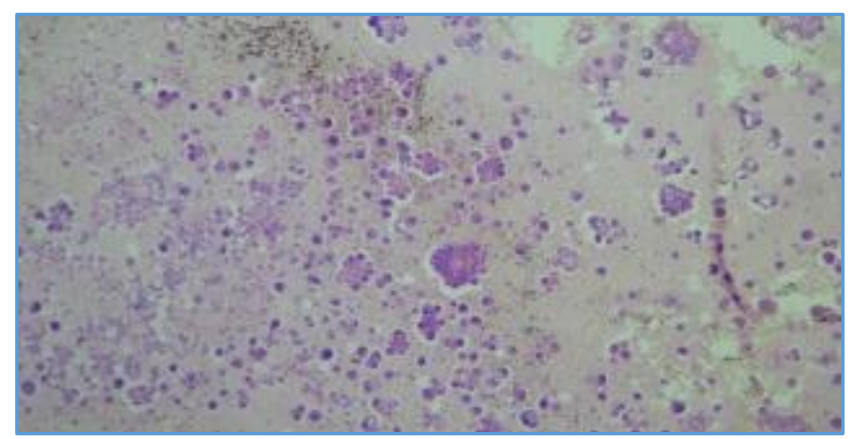

Image 8. Low Power H and E: Cell Block Cytology from Pleural Fluid Sediments Smear shows Round-to-Oval Tumour Cells Arranged in Acinar-Glandular Pattern

Positive for Malignant Cells (PFM) s/o Adenocarcinoma Lung

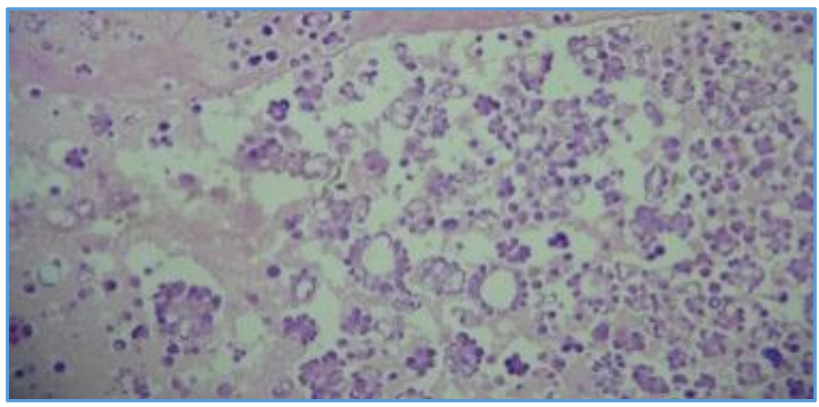

Image 9. Low Power- H and E Smear shows Tumour Cells arranged in Glandular and at places in Papillary Pattern. Positive for Malignant Cells (PFM) S/O Adenocarcinoma

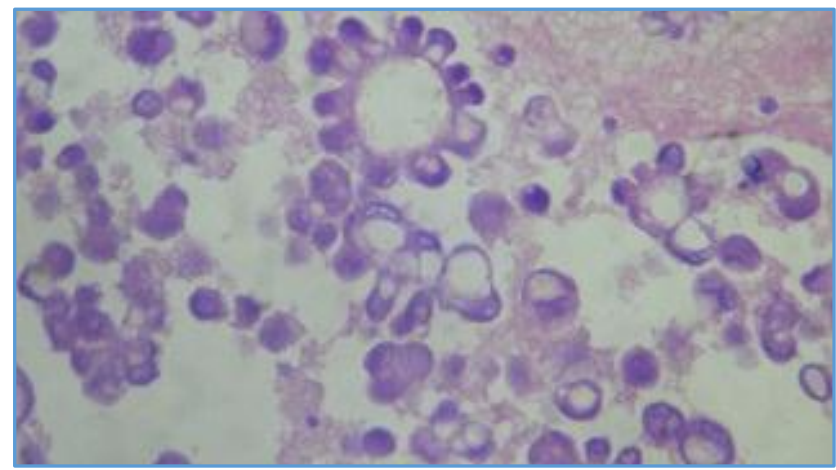

Image 10. High Power- H and E-Smear shows Presence of Tumour Cells having Hyperchromatic, Pleomorphic, Eccentric Nuclei and Moderate Amount of Cytoplasm arranged in Glandular Pattern. Positive for Malignant (PFM) Cell S/O Adenocarcinoma Lung

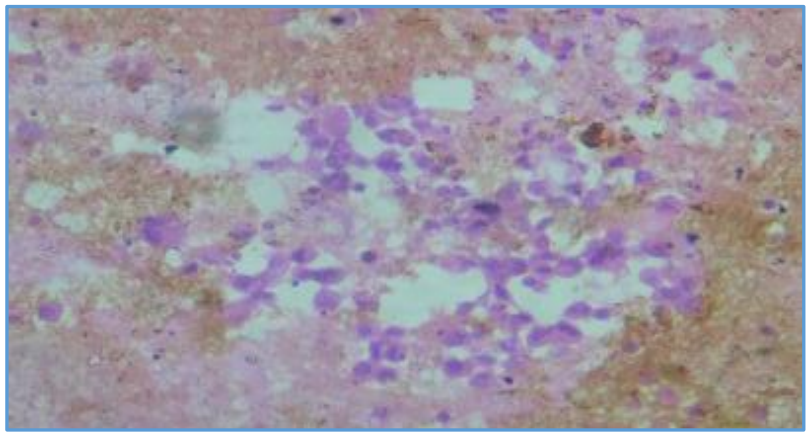

Image 11. Cell Block Cytology H and E High Power-Smear shows Presence of Tumour Cells having HyperchromaticPleomorphic Nuclei and Moderate Amount of Eosinophilic Cytoplasm arranged in Sheets and Clusters.

Positive for Malignant (PFM) cells- squamous cell carcinoma lung.

\section{RESULTS}

In this study, 75 cases were studied during January 2013 to June 2014. All samples of patients with suspected lung malignancies are processed on conventional smear and cell block.

The following Results were made with regard to-

\begin{tabular}{|c|c|c|}
\hline Sl. No. & No. of Cases & Percentage \\
\hline Male & 32 & $66.66 \%$ \\
\hline Female & 16 & $33.33 \%$ \\
\hline Total & 48 & $100 \%$ \\
\hline \multicolumn{3}{|c|}{$\begin{array}{c}\text { Table 1. Distributions of Cases with Lung Malignancies } \\
\text { according to } \operatorname{Sex}(n=48)\end{array}$} \\
\hline
\end{tabular}

Table 10 shows Male (66.66\%) patients are more affected than female $(33.33 \%)$ patients with lung malignancy. Maleto-Female ratio is 2: 1 .

Males are more affected than females. This is due to smoking habits, exposure to carcinogens at work place.

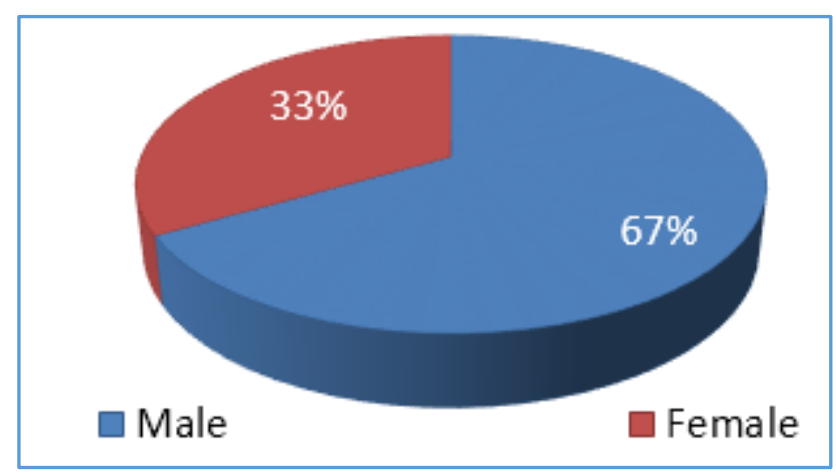

Graph 1. Shows Distribution of Cases with Lung Malignancies according to Sex 


\begin{tabular}{|c|c|c|c|}
\hline Sl. No. & Age Range & No. of Patients & Percentage (\%) \\
\hline 1 & $11-20$ & 00 & $00 \%$ \\
\hline 2 & $21-30$ & 00 & $4.16 \%$ \\
\hline 3 & $31-40$ & 02 & $6.25 \%$ \\
\hline 4 & $41-50$ & 03 & $22.91 \%$ \\
\hline 5 & $51-60$ & 27 & $4.16 \%$ \\
\hline 6 & $61-70$ & 11 & $4.16 \%$ \\
\hline 7 & $71-80$ & 02 & $2.08 \%$ \\
\hline 8 & $81-90$ & 02 & $\mathbf{1 0 0 \%}$ \\
\hline 9 & $91-100$ & 01 & \\
\hline Total & \multicolumn{2}{|c|}{ Table 2. Distribution of Lung Malignancies according to Age (n= 48) } \\
\hline \multicolumn{2}{|c|}{} \\
\hline
\end{tabular}

Above table shows maximum number of cases with lung malignancies are from age range 51 - 60 years (56.25\%) followed by 61 - 70 years $(22.91 \%), 41-50$ years $(6.25 \%)$, $71-80$ and 81 - 90 years (4.16\%), 91 - 100 years $(2.08 \%)$.

Patients with age below 30 years of age are not found.

\begin{tabular}{|c|c|c|c|}
\hline Sl. No. & Residence & No. of Patients & Percentage (\%) \\
\hline 1 & Urban & 14 & $29.16 \%$ \\
\hline 2 & Rural & 34 & $70.83 \%$ \\
\hline Total & Table 3. Urban-Rural Ratio of Patients with Lung Malignancies (n= 48) \\
\hline \multicolumn{2}{|c|}{}
\end{tabular}

Above table shows that $34(70.83 \%)$ patients belonged to rural area and remaining 14 (29.16\%) patients belonged to urban area. Urban: Rural ratio was found to be $0.41: 1$.

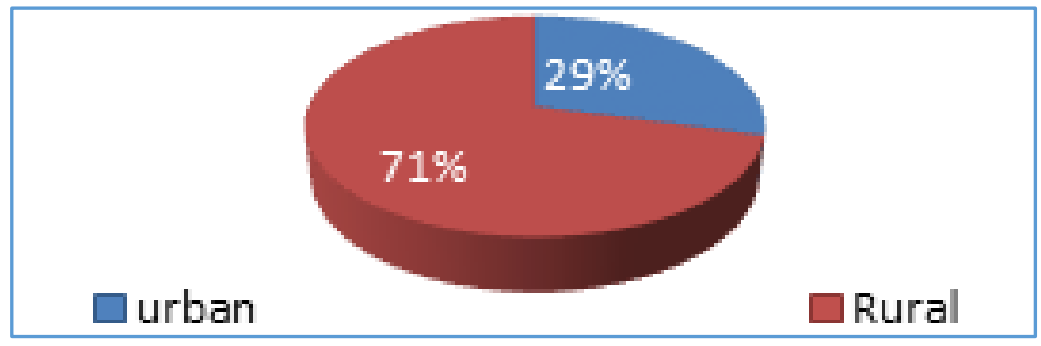

Graph 2. Showing Urban-Rural Distribution

\begin{tabular}{|c|c|c|c|}
\hline Sl. No. & Occupation & No. of Patients & Percentage (\%) \\
\hline 1 & Farmer & 14 & $29.16 \%$ \\
\hline 2 & Labourer & 20 & $21.66 \%$ \\
\hline 3 & Clerks/ Teacher & 01 & $25 \%$ \\
\hline 4 & Housewives & 12 & $2.08 \%$ \\
\hline 5 & Others & 01 & $\mathbf{1 0 0} \%$ \\
\hline Total & \multicolumn{2}{|c|}{ Table 4. Distribution of Cases with Lung Malignancies according to Occupation (n= 48) } \\
\hline
\end{tabular}

Above table shows maximum number of patients with lung malignancies are labourers (41.66\%) by occupation followed by Farmers (29.16\%), Housewives (25\%), Clerks/ Teachers (2.08\%).

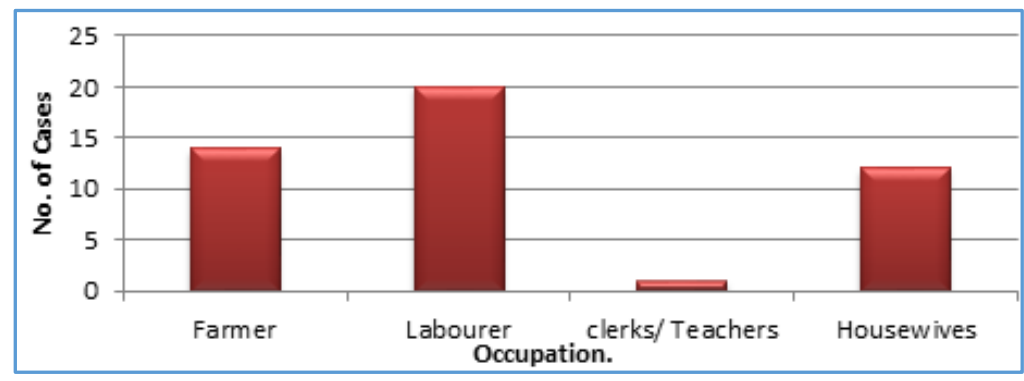

Graph 3. Shows Distribution of Cases according to Occupation 


\begin{tabular}{|c|c|c|c|}
\hline Sl. No. & Clinical Presentation & No. of Patients & \% \\
\hline 1 & Cough with Expectoration & 35 & $72.91 \%$ \\
\hline 2 & Chest Pain & 30 & $62.50 \%$ \\
\hline 3 & Breathlessness/ Dyspnoea & 30 & $62.50 \%$ \\
\hline 4 & Haemoptysis & 25 & $52.08 \%$ \\
\hline 5 & Fever & 10 & $20.83 \%$ \\
\hline 6 & Lymphadenopathy & 01 & $2.08 \%$ \\
\hline \multicolumn{2}{|c|}{ Table 5. Clinical Presentation of Patients with Lung Malignancy (n= 48) } \\
\hline
\end{tabular}

Above table shows that Cough with Expectoration seen in 35 patients $(72.91 \%)$ is the most common clinical presentation of patient with lung malignancy followed by chest pain and breathlessness seen in 30 patients $(62.50 \%)$ followed by Haemoptysis seen in 25 patients $(52.08 \%)$ followed by fever seen in 10 patients (20.83\%) and the least common presentation is patients with lymphadenopathy seen in 1 patient $(2.08 \%)$.

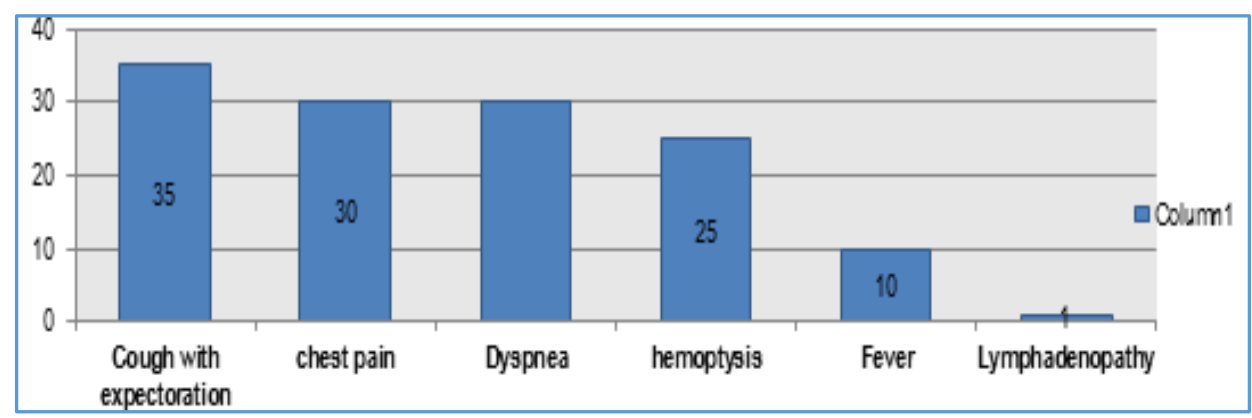

Graph 4. Shows Clinical Presentation of Patients with Lung Malignancy

\begin{tabular}{|c|c|c|c|}
\hline Sl. No. & Smoking Status & No. of Patients & (\%) \\
\hline 1 & Smokers & 38 & $29.16 \%$ \\
\hline 2 & Non-Smokers & 10 & $20.83 \%$ \\
\hline \multicolumn{2}{|c|}{ Total } & $\mathbf{4 8}$ & $\mathbf{1 0 0 \%}$ \\
\hline
\end{tabular}

Above table shows distribution of cases according to smoking status of patients with lung malignancies. 38

(79.16\%) patients are smokers, while 10 (20.83\%) patients are non-smokers. Smoker: Non-smoker ratio is 3.80 : 1.

\begin{tabular}{|c|c|c|c|}
\hline Sl. No. & Form of Smoking & No. of Patients & (\%) \\
\hline 1 & Bidi & 30 & $78.94 \%$ \\
\hline 2 & Cigarette & 07 & $18.42 \%$ \\
\hline 3 & Hukka & 01 & $2.63 \%$ \\
\hline 4 & Other & 00 & $00.00 \%$ \\
\hline Total & Table 7. Form of Smoking used by Patients Addicted with Lung Malignancies (n= 38) \\
\hline \multicolumn{2}{|r}{} \\
\hline
\end{tabular}

Above table shows that Bidi is the most common form of tobacco smoking seen in $30(78.94 \%)$ patients followed by cigarette (18.42\%) smoking and Hukka smoking (2.63\%).

Bidi is easily available and cheap; hence, it may be the commonest form of smoking.

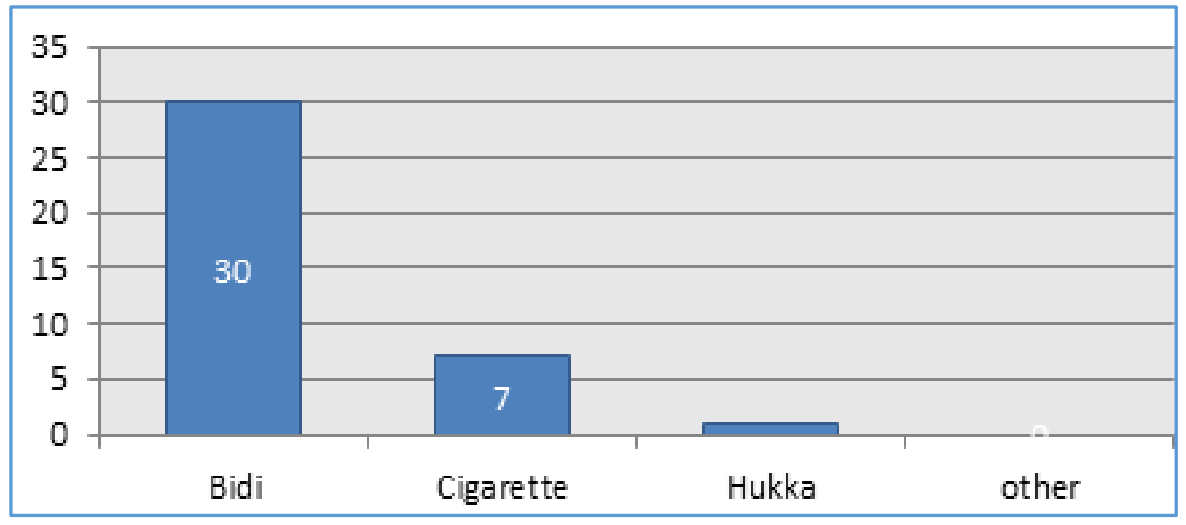

Graph 5. Showing Distribution of Patients according to Form of Smoking 


\section{DISCUSSION}

In this study, $10 \%$ Alcohol-Formalin is used as a fixative for modified cell block preparation. By this better cellularity is obtained compared to conventional smear, as formalin minimises cell loss by forming protein cross links.

\begin{tabular}{|c|c|c|c|}
\hline Sl. No. & Authors & $\begin{array}{c}\text { Most Common Age Group of Patients with Lung } \\
\text { Malignancy }\end{array}$ & Percentage (\%) \\
\hline 1 & N. Kirmani et al 20101 & $51-60$ years & $33.33 \%$ \\
\hline 2 & Prabhat et al 20132 & $50-60$ years & $36.63 \%$ \\
\hline 3 & Present Study & $51-60$ years & $56.25 \%$ \\
\hline \multicolumn{2}{|r|}{ Table 8. Comparative Study of most common Age Group involved in Patients with Lung Malignancies } \\
\hline
\end{tabular}

In study conducted by N. Kirmani et $\mathrm{al}^{1} 2010$ found that most common age group of patients with lung malignancies was 51 - 60 years (33.33\%). In study by Prabhat et al2 2013, also found that maximum number of patients with lung malignancies belong to age group 51 - 60 years $(36.63 \%)$.
In our study, we also found 51 - 60 years $(56.25 \%)$ is the most common age group involved.

Our study is comparable with N. Kirmani et al ${ }^{1} 2010$ and Prabhat et $\mathrm{al}^{2} 2013$.

\begin{tabular}{|c|c|c|}
\hline Sl. No. & Authors & Male: Female Ratio \\
\hline 1 & Bahera D et al 20043 & $5.76: 1$ to $6.67: 1$ \\
\hline 2 & Prabhat et al 20132 & $4.6: 1$ \\
\hline 3 & Sanjeetkumar et al 20134 & $1.09: 1$ \\
\hline 4 & Present Study & $2: 1$ \\
\hline \multicolumn{2}{|c|}{ Table 9. Comparative Study of Male: Female Ratio of Patients with Lung Malignancy in Different Studies } \\
\hline
\end{tabular}

In study by Bahera D et $\mathrm{al}^{3} 2004$ found that Male: Female ratio of patients with lung malignancy ranged from 5.76 to 6.67: 1 .

Prabhat et $\mathrm{al}^{2} 2013$, ratio was found to be 4.6: 1 .

Sanjeetkumar et al 4 2013, Male-to-Female ratio found to be 1.09: 1 .
In our study, we found ratio of 2: 1 .

In all the studies, males are more affected than females. This is due to smoking habits in males and more exposure to occupational carcinogen at work place.

Our study is comparable with Sanjeetkumar et al ${ }^{4} 2013$.

\begin{tabular}{|c|c|c|}
\hline Sl. No. & Authors & Smoker: Non-smoker Ratio \\
\hline 1 & $\begin{array}{c}\text { Jindal and Behera } \\
\text { et al } 1990^{3}\end{array}$ & $2.7: 1$ \\
\hline 2 & Sanjeetkumar et al 20134 & $3.7: 1$ \\
\hline 3 & Present Study & $3.8: 1$ \\
\hline \multicolumn{2}{|c|}{ Table 10. Comparative Study of Smoker: Non-Smoker Ratio in Patients with Lung Malignancy } \\
\hline
\end{tabular}

Study done by Jindal and Behera et $\mathrm{al}^{3} 1990$ found that ratio is $2.7: 1$.

Sanjeetkumar et $\mathrm{al}^{4} 2013$ found smoker: non-smoker ratio is $3.7: 1$.

\begin{tabular}{|c|c|c|c|c|c|c|}
\hline \multirow[b]{2}{*}{ Sl. No. } & \multirow[b]{2}{*}{ Authors. } & \multicolumn{5}{|c|}{ Clinical Presentation } \\
\hline & & $\begin{array}{c}\text { Cough with } \\
\text { Expectoration }\end{array}$ & Chest Pain & Dyspnoea & Haemoptysis & Fever \\
\hline 1 & Behera D et al $1990^{3}$ & $88 \%$ & $52.2 \%$ & NR & $69.2 \%$ & $19.6 \%$ \\
\hline 2 & Prabhat et al $2013^{2}$ & $57.41 \%$ & $50.16 \%$ & NR & $18.08 \%$ & NR \\
\hline 3 & Sanjeetkumar et al $2013^{4}$ & $36.34 \%$ & $7.92 \%$ & $11.89 \%$ & $6.82 \%$ & NR \\
\hline 4 & Present Study & $72.91 \%$ & $62.50 \%$ & $62.50 \%$ & $52.08 \%$ & $20.83 \%$ \\
\hline
\end{tabular}

NR- Not Reported.

In study done by Behera D et $\mathrm{al}^{3} 2004$ found that Cough with Expectoration (88\%) was the most clinical presentation of patients with Lung Malignancy followed by haemoptysis (69.2\%) and chest pain (52.2\%).

Study done by Prabhat et al2 2013 (57.03\%) and
In our study, found Smoker: Non-smoker ratio is 3.8: 1. This study is comparable with Sanjeetkumar et $\mathrm{al}^{4}$ study. 


\begin{tabular}{|c|c|c|c|c|c|c|}
\hline \multirow{2}{*}{ Sl. No. } & Authors & Farmers & Labourer & Clerk/Teacher & Housewives & Others \\
\cline { 2 - 6 } & $\begin{array}{c}\text { Behera D } \\
\text { et al 2004 }\end{array}$ & $30.95 \%$ & $24.15 \%$ & $16.7 \%$ & $15.35 \%$ & $15 \%$ \\
\hline 1 & $\begin{array}{c}\text { Present } \\
\text { Study }\end{array}$ & $29.16 \%$ & $41.66 \%$ & $2.08 \%$ & $25 \%$ & $2.08 \%$ \\
\hline
\end{tabular}

Study done by Behera et $\mathrm{al}^{3} 2004$, found that farmers (30.95\%) were most commonly affected occupation followed by labourers $(24.15 \%)$ than others in patients with lung malignancy.
In our study, we found labourers (41.66\%) are the most common affected occupation followed by farmers $(29.16 \%)$ and housewives (25\%).

\begin{tabular}{|c|c|c|c|c|}
\hline \multirow{2}{*}{ Sl. No. } & \multirow{2}{*}{ Authors } & \multicolumn{3}{|c|}{ Form of Smoking } \\
\hline & & Bidi & Cigarette & Others \\
\hline 1 & Prabhat et al $2013^{2}$ & $55.25 \%$ & $28.45 \%$ & $16.30 \%$ \\
\hline 2 & Present Study & $78.94 \%$ & $18.42 \%$ & $2.63 \%$ \\
\hline
\end{tabular}

Study done by Prabhat et $\mathrm{al}^{2}$ 2013, found that Bidi (55.25\%) is the most common form of smoking associated with patients with lung malignancy followed by cigarette smoking (28.45\%).

In our study, we also found Bidi (78.94\%) is the most common form of smoking used by patients with lung malignancy followed by cigarette smoking (18.42\%).

\section{Summary}

We conducted a study of diagnosis of lung malignancy by cell block method, we study a total of 75 samples from clinically suspected patients with lung malignancies. We found 48 patients with lung malignancy. We found in our study-

1. Incidence of lung malignancy is more in Males (66.66\%) than in Females $(33.33 \%)$ due to smoking pattern and occupational exposure to hazardous carcinogens.

2. Lung malignancy most commonly affects older population. People with age more than 50 are at more risk. Patients with age group 51 - 60 years (56.25\%) are most affected.

3. People living in rural (70.83\%) areas are at more risk of developing lung cancer as compared to people living in urban $(29.16 \%)$ areas due to smoking habits and more exposure to environmental carcinogen.

4. Labourers (41.66\%) are most affected population than other occupation due to occupational exposure to industrial carcinogens.

5. People having history of smoking (79.16\%) are more prone to develop lung malignancies than non-smokers (20.83\%).

6. Bidi $(78.94 \%)$ is the most common indigenous smoking pattern used by patients, as it is easily available and cheap.

7. Right lung (68.75\%) tend to involve more than left lung $(31.25 \%)$ in cases of lung malignancy.

8. Due to changing pattern, filtered smoke cigarettes in market increased in number of female smokers and more exposure of females to household environmental carcinogens. Adenocarcinoma (75\%) is the most common histological subtype found.

\section{CONCLUSION}

1. Cell block technique by using $10 \%$ alcohol-formalin as a fixative is simple, inexpensive and does not require special training and instrument.

2. Morphological features are better appreciated by cell block method as compared with conventional smear.

3. Multiple sections can be obtained if required for special stain and immunohistochemistry (IHC) studies.

4. Sensitivity of malignant cases by cell block method was significantly increased as compared with conventional smear method.

5. With increasing prevalence of smoking, lung cancer has reached epidemic proportions.

6. In addition to smoking, occupational exposure to carcinogens, indoor air pollution and dietary factors have presently implicated in causation of lung malignancy.

7. Various modalities for early detection through screening are being investigated. Majority of patients have locally advanced or disseminated disease at presentation and are not candidates for surgery.

8. Chemotherapy applied as an adjuvant with radiation improves survival and quality of life, hence appropriate histological diagnosis is needed for proper treatment.

9. New anticancer drugs, which have emerged during the last decade have shown an improved efficacy in treatment of lung malignancy.

10. In view of our large population, the burden of lung cancer will be quite enormous in India.

11. Drastic measures aimed at discouraging people from smoking must be taken to reduce the morbidity and mortality due to lung malignancy.

\section{REFERENCES}

[1] Kirmani N, Jamil K, Naidu M. Occupational and environmental carcinogens in epidemiology of lung cancer in South Indian population. Biology and Medicine 2010;2(4):1-11.

[2] Malik PS, Sharma MC, Mohanti BK, et al. Clinicopathological profile of lung cancer at AIIMS: a changing paradigm in India. Asian Pac J Cancer Prev 2013;14(1):489-94. 


\section{Jemds.com}

[3] Behera D, Balamugesh T. Lung cancer in India. Indian J Chest Dis Allied Sci 2004;46(4):269-81.
Original Research Article

[4] Mandal SK, Singh TT, Sharma TD, et al. Clinicopathology of lung cancer in a regional cancer center in Northeastern India. Asian Pac J Cancer Prev 2013;14(12):7277-81. 